\title{
O fausto de Helena no convento de Manoel de Oliveira
}

\author{
Maria Cecilia de Miranda Nogueira Coelho \\ Universidade Federal de Minas Gerais
}

\begin{abstract}
Mas o que eu deduzo da Agustina nos seus livros - e tenho dito isso várias vezes, - o que mais gosto nos seus livros, é o que há de irracional.
\end{abstract}

Conversas no Porto, Manoel de Oliveira. ${ }^{1}$

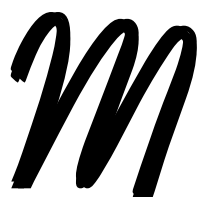

eu objetivo neste texto é o de analisar alguns aspectos da caracterização da personagem Hélène no filme O Convento (1995), de Manoel de Oliveira. Buscarei mostrar como o diretor reapresentou a figura de Helena de Tróia, citada tantas vezes no romance cujo argumento originou o filme - As terras do risco, de Agustina Bessa-Luís -, fazendo alusões muito sutis e significativas a esta famosa personagem mítica. Desnecessário dizer que a bela espartana continua, após tantos séculos, desde seu papel na Ilíada, a aparecer frequentemente, seja como figura individualizada, seja como metáfora de imagem feminina, em obras da literatura, iconografia, ópera e cinema. Como sabemos, de Homero aos cineastas contemporâneos, são inúmeras as figurações de Helena em imagens sedutoras ao longo da cultura ocidental que despertam apreciações e julgamentos os mais diversos.

${ }^{1}$ AVELLA, 2007, p. 70. 
Que a presença de Helena seja metáfora, alegoria ou símbolo da própria mulher é o que o verso de Goethe expressa, ao fazer Mefistófeles dizer a Fausto que, ao ingerir a poção do amor, ele "verá Helena em toda mulher". ${ }^{2}$ Fausto, de Goethe, é, aliás, obra particularmente significativa para este artigo, pelo fato de ser citada muitas vezes no livro As terras do risco, e de ter alguns de seus versos lidos e comentados em várias cenas do filme $O$ Convento, principalmente em uma das cenas finais, conduzindo a um fechamento e propondo determinada interpretação para toda a narrativa de Manoel de Oliveira. Dentre tantas outras, esta obra de Goethe permite-nos mostrar a presença e permanência significativa de Helena de Tróia no imaginário literário, reverberando e aludindo a outras figurações suas. Lembremos que no início da segunda parte do Fausto há um diálogo entre Helena e Fórquias, do qual foram retirados os versos abaixo. Os versos aludem, certamente, às duas versões do mito de Helena: uma, mais famosa, de que Helena foi para Ílion/Tróia, sendo responsável pela guerra entre bárbaros e gregos; outra, de que ela não esteve ali, mas ficou no Egito, casta qual Penélope, tendo sido um fantasma, eídolon forjado pela divina Hera, colocado em seu lugar, iludindo a todos gregos e troianos.

${ }^{2} \mathrm{O}$ verso foi utilizado como título do livro de Barbara Cassin, CASSIN, 2001, em que são analisadas várias representações de Helena nas literaturas grega clássica e moderna. Quanto a análises da complexa figura de Helena, veja, no campo da história da literatura, GUMPERT, 2001. Sobre as transformações da figura de Helena em obras de Homero, Virgílio, Spenser e Shakespeare, veja SUZUKI, 1989. Na perspectiva da relação entre filosofia, retórica e literatura, veja COELHO, 2002b. 
Helena: Sendo uma, o mundo perturbei: mais, dúplice; Tríplice, quádrupla, amontôo infortúnios. [.....................................................]

Fórquias: Mas narram que em visão dúplice apareceste Pois foste vista em Ílio e no Egito igualmente

Helena: Não me atordoes de todo senso alucinado; Neste momento, até, ignoro quem eu seja. ${ }^{3}$

Na tragédia Helena, de Eurípides, a verdadeira Helena ficou guardada por Proteu e após sua morte, por seu filho Teoclímeno. Na volta de Tróia, Menelau reencontrou esta outra Helena, enquanto a que ele trouxera de Tróia, desapareceu, voltando ao éter. Assediada e vigiada pelo pretendente, Helena planeja um esquema para a fuga do Egito. Para fugirem, Menelau se passou por um náufrago grego, trazendo notícias de sua própria morte. Helena, interpretando uma viúva e auxiliada pelo marido disfarçado, preparou um funeral simbólico com um sacrifício em alto-mar, o que possibilitou o retorno do casal a Esparta. Sobre essa Helena inocente, sabemos que Eurípides não inovou nem pela referência ao eídolon, pois esse já havia aparecido na Palinódia, obra do poeta Estesícoro, nem pelo fato de Helena ter estado no Egito, episódio relatado em Homero (Odisséia, IV) e Heródoto (História, II, 116-120). ${ }^{4}$ Mesmo que a versão de Estesícoro tenha sido bastante famosa (ela é citada, aliás, por Platão Fed. 243b, Carta III, 319e) e tenha inspirado Eurípides, uma influência importante, que concerne, principalmente, ao enredo da peça, é a de Homero. ${ }^{5}$ Sobre esta

${ }^{3}$ GOETHE, 1991, p. 344-346.

${ }^{4}$ Para um estudo destas questões em Estesícoro, veja BOWRA, 1961, p. 74-129; AUSTIN, 1994, BASSI, 1993, p. 51-75.

${ }^{5} \mathrm{O}$ tema já foi analisado por vários helenistas. Veja, por exemplo, EISNER, 1980; FOLEY, 1992; KAKRIDIS, 1972. 
casta Helena, lembremos, no entanto, que a 'Helena real', como querem alguns, ${ }^{6}$ exceto por não ter estado na cama de um bárbaro, mantém todas as características do eídolon que estava em Tróia: beleza, capacidade de atrair os homens, habilidade persuasiva, poder de causar sofrimento (aos egípcios, agora), uma mistura de caráter ativo - ela é que elabora o plano de fuga para a Grécia - e passividade - seu corpo continua sendo um objeto de troca e negociações. Neste sentido, ela faz jus àquela hábil Helena que vemos na Odisséia (IV, v. 220-1), manipulando o discurso (lógos) e as drogas (phármakon). ${ }^{7}$

Assim como nas suas representações de Helena (seja nas peças Helena, As Troianas, ou em outras peças) Eurípides combinou elementos de várias versões da lenda, Goethe também parece estar combinando referências variadas: lembremonos, por exemplo, da famosa pergunta "Foi esta a face que lançou mil navios e queimou as torres inalcançáveis de Ílion?' na peça The Tragical History of Doctor Faustus, escrita no século XVI, por Christopher Marlowe, ao falar da guerra de Tróia. Curiosamente, na primeira versão do Fausto de Goethe temos apenas a presença de Margarida; Helena será um acréscimo posterior. ${ }^{8}$ Como disse, o Fausto de Goethe é importante, aqui, pelas referências explícitas que tanto Manoel de Oliveira como Agustina Bessa-Luís fizeram a esta obra. Mas antes de falarmos delas, vejamos mais três representações de Helena muito significativas na literatura dos séculos XIX e XX.

Helena é o nome de um poema de Giorgos Seferis (prêmio Nobel em 1966), que foi publicado em 1953, e que tem como epígrafe os versos 148-150 da tragédia Helena, de Eurípides.

${ }^{6}$ Um exemplo paradigmático é SEGAL, 1986 (1971).

${ }^{7}$ Sobre o tema, veja COELHO, 2009.

${ }^{8}$ Veja GOETHE, 2001. 
Como nos indicam os versos seguintes, a incerteza sobre as relações entre o divino e o humano e a sedução de um nome, um fantasma, continuam perturbadoras.

E em Tróia?

Nada em Tróia - apenas um fantasma.

Assim os deuses o quiseram.

E Páris se deitou com uma sombra com se ela fosse um

Ente sólido.

E por Helena durante dez anos fomos massacrados. [...]

Por uma túnica vazia uma Helena.

[...]

Solitário ancorei com esta fábula,

Se é verdade que de fábula se trata,

Se é verdade que os homens não irão cair de novo

No velho engano dos deuses; 9

A força deste nome/personagem e a impossibilidade de compreender tamanha beleza associada a tantos sofrimentos e incertezas no ocidente, já assombravam a Grécia do século V. O nome de Helena tem um peso ímpar devido à etimologia esquiliana forjada na tragédia Agamêmnon, "a que arrasta à perdição navios, homens e cidades" (v. 687-8) ${ }^{10}$ e lembrada por Górgias no famoso e polêmico Elogio a Helena: "mulher em torno

9 PAES, 1995, p. 170.

${ }^{10}$ Ésquilo sugere a origem comum de seu nome e de uma forma verbal de airéo (que significa arrasar, destruir). Apesar de não ser personagem na peça esquiliana, Helena paira de maneira assombrosa na trama da Orestéia, principalmente na primeira peça da trilogia. Sobre o assunto, veja COELHO, 2000. Para uma estudo mais descritivo das referências a Helena na antigüidade grega, veja CALAME, 1981. 
da qual, uníssona e unânime é a crença dos que ouviram os poetas e a fama do nome, que se tornou memento de males" $(E . H, 2) .{ }^{11}$ Recorrente é essa "memória do nome" manifestandose ao longo dos séculos de modo tão peculiar, designando muitas e variadas faces a que o nome se aplica. Paradoxalmente, este nome é a própria face de todo um povo, o que constatamos por meio desta afirmação de Nietzsche, em texto muito significativo para a tradição filosófica e dramática, e por meio do qual vemos como o encantamento de Helena ainda perdura na modernidade. Helena é metáfora da própria condição de ser grego, como nos mostra o seguinte trecho do Nascimento da Tragédia (§ 3):

E assim, é possível que o observador fique realmente surpreendido ante essa fantástica exaltação da vida e se pergunte com qual filtro mágico no corpo puderam tais homens exuberantes desfrutar da vida a ponto de se depararem, para onde quer que olhassem, com o riso de Helena - a imagem ideal, "pairando em doce sensualidade", da própria existência deles. ${ }^{12}$

Que a imagem de Helena tenha saído dos limites da Europa, reaparecendo em tantas outras paragens, não é difícil de investigar. Tomo apenas um exemplo de sua presença em um dos expoentes da língua portuguesa, Machado de Assis. $\mathrm{O}$ escritor, leitor confesso dos clássicos gregos, não apenas nos legou um romance chamado Helena, com uma protagonista muito sedutora e cuja história tem semelhanças significativas com a da tragédia Helena, de Eurípides, ${ }^{13}$ mas também usou este

\footnotetext{
11 Tradução da autora. In: COELHO, 1999.

12 NIETSZCHE, 1993.

${ }^{13}$ Sobre as aparições de Helena no romance homônimo, nos contos, e na peça Lição de Botânica, veja COELHO, 2002a.
} 
nome para várias personagens, não deixando de fazer, também, comparações perspicazes entre episódios do mito de Helena e acontecimentos contemporâneos, como é indicado na seguinte passagem:

Outro telegrama conta-nos que alguns clavinoteiros de Canavieiras (Bahia) foram a uma vila próxima e arrebataram duas moças. A gente da Vila ia armar-se e assaltar Canavieiras. Parece nada e é Homero; é ainda mais que Homero que só contou o rapto de uma Helena: aqui são duas. Essa luta obscura, escondida no interior da Bahia, faz singular contraste com a outra que se trava no Rio Grande do Sul, onde a causa não é uma, nem duas Helenas, mas um só governo político. Apuradas as contas vem a dar nessa velha verdade, que o amor e o poder são as duas forças principais da terra. Duas vilas disputam a posse de duas moças; Bagé luta com Porto Alegre pelo direito de mando. É a mesma Ilíada. ${ }^{14}$

Aqui entramos em um terreno delicado, que é o de ver a personagem se transformar em outras mulheres (gregas ou não), em diferentes épocas. $\mathrm{O}$ fato de uma personagem ser chamada de Helena, nome hoje bastante comum, não estabelece, naturalmente, vínculo imediato com a famosa espartana. Naturalmente são necessários outros elementos e algum contato com a tradição clássica grega e suas citações posteriores. Neste sentido, os aspectos relembrados acima, relativos a caracterizações de Helena tanto na antiguidade como na modernidade, auxiliam-nos a analisar como Manoel de Oliveira e Agustina Bessa-Luís fizeram a transposição de Helena para o século XX, no contexto da vida acadêmica e da sociedade burguesa ocidental.

${ }^{14}$ MACHADO DE ASSIS, 1997, p. 538. 
Como estamos tratando, precipuamente de uma obra cinematográfica, e de um texto escrito em 1994, não há como desconsiderar as possíveis influências das imagens de tantas Helenas levadas à tela no século do cinema, personificadas pelas mais belas atrizes e estrelas de cada época. Já nos anos 1920, temos duas obras sofisticadas na caracterização de Helena: Helena de Tróia (Manfred Noa, 1924) e A vida Privada de Helena de Tróia (A. Korda, 1927), baseado no romance homônimo, de John Erskine, 1925, este último, filme, infelizmente, de difícil acesso. ${ }^{15}$ Em 1956, mesmo ano do lançamento do épico de Robert Wise, Helena de Tróia, com Rosana Podestá, Jean Renoir lançava, Eléna et les hommes, com Ingrid Bergman, elogiado por Rohmer, Truffaut, e Godard. ${ }^{16} \mathrm{Na}$ década de sessenta, destacam-se O Leão de Thebas (G. Ferroni, 1964, Itália) e Dr. Faustus (R. Burton, 1968, Inglaterra, no qual Helena é interpretada por Elisabeth Taylor) e na década seguinte, temos uma das mais destacadas representações de Helena, feita por Irene Papas, em As Troianas, adaptação de Michael Cacoyannis da tragédia homônima de Eurípides. Neste último filme, a primeira imagem que vemos dela, por meio de um close dos seus olhos, parece ser uma clara referência, imagética ao texto da peça, no qual Hécuba, rainha derrotada dos troianos, suplica a Menelau que não olhe nos olhos de sua esposa, temendo o efeito do olhar tão poderoso sobre o antigo marido: "escapa de

${ }^{15}$ Existe apenas uma cópia (em película) de duas partes deste filme, que está guardada nos arquivos do British Film Institute, em Londres. Pude assistir, em 2008, sob condições especiais, como pesquisadora, a esta cópia do filme, cuja versão integral, infelizmente se perdeu.

${ }^{16}$ Cahiers du Cinéma, 78, 1957, p. 86. Para uma análise do filme de Renoir, veja COELHO, 2007. 
vê-la, ... pois agarra o olhar dos homens, arrasa cidades, queima casas, assim é seu charme". ${ }^{17}$

Há outro grupo de filmes em que a referência à personagem mítica individualizada é mais complexa. Vislumbramos a presença de Helena pela fama do nome, que, associado a outros elementos na construção da personagem ou na trama, indica que nomen est omen. São exemplos os filmes Ao sul do meu corpo (J.P. Saraceni, 1982) e Duas vezes com Helena (M. Farias, 2002), ambos adaptações de um conto de Paulo Emílio Salles Gomes (escritor e criador da Cinemateca Brasileira), Duas vezes com Helena, de 1977, que, por sua vez, havia trabalhado no roteiro de Memória de Helena (David Neves, 1969). ${ }^{18}$ Lembremonos também de Ingmar Bergman - sempre tão criterioso e consistente na escolha de nomes - ao construir os personagens de Fanny e Alexander: como não notar a relação tão especial entre o menino Alexander e sua avó Helena (matriarca de uma família de artistas de teatro)? Outro exemplo instigante é Dames $d u$ Bois de Boulogne (R. Bresson, 1945), baseado em um episódio do romance Jacques le Fataliste et Son Maître, de Denis Diderot, no qual Bresson muda os nomes de Mme. La Pommeraye e de Mlle. d'Aisnon para Hélène (interpretada por Maria Casares) e Agnès, respectivamente. ${ }^{19}$ Por fim, citemos Encaixotando Helena

Troianas, versos 892-3. Diferentes e significativas referências ao poder do olhar de Helena e de sua imagem como objeto do olhar dos outros podem ser vistas também em Homero (Ilíada III, na famosa cena da teichoscopia), Górgias (no Elogio a Helena) e Eurípides (nas tragédias Helena e Hécuba).

${ }^{18}$ Sobre estes filmes, veja COELHO, 2010. Também encontramos, ainda que sob o signo da paródia, Carnaval Atlântida (J.C. Burle, 1952), no qual Helena, dada a impossibilidade de se fazer o gênero épico no Brasil, terminará na avenida, pulando carnaval.

${ }^{19}$ Para uma análise deste filme, veja COELHO, 2008a. 
(J. Lynch, 1993) e Tio Vanya em Nova York (L. Malle, 1994), com suas alusões menos explícitas, mas não menos poderosas. Vemos, em todos estes esta personagem - como já dissera Górgias - manifestar-se de modo tão recorrente e peculiar, com poder análogo ao descrito por Górgias: "Helena, que com um só corpo reuniu muitos corpos de homens..." (Elogio de Helena, 4).

No caso da filmografia de Manoel de Oliveira, vemos que a figura de Helena não parece ter sido abandonada, pois em Um filme falado (2003), faz Irene Papas (um ícone na cinematografia grega e uma inesquecível Helena, sob a direção de M. Cacoyannis), personificar a Grécia, proferindo um discurso que analisa as idiossincrasias da imagem da Hélade como berço da civilização ocidental, sem deixar, no entanto, de reforçar esta imagem, até por meio de seu nome, Helena. ${ }^{20}$ No entanto, neste caso, ao colocá-la em um navio que faz uma jornada pelo Mediterrâneo, Oliveira não deslocou tanto a famosa espartana - já que sua viagem a Tróia, no navio de Páris, foi tão marcante a ponto de ela ser reconhecida por este epíteto, mais do que por sua terra natal-, como o fez ao levá-la para um convento. Que lugar interessante para se falar daquela que era criticada por se dedicar unicamente à sua beleza e preferir o fausto troiano à simplicidade espartana (e grega). O que Oliveira faz (e também Bessa-Luís, como veremos em seguida) é realçar a exuberância desta mulher ao usar como cenário um

${ }^{20}$ Outro caso interessante em que se faz este tipo de alegoria é o dos dois últimos filmes de Theo Angelopoulos, Vale dos Lamentos e A Poeira do Tempo, nos quais é retomada a figura emblemática de Helena em sua protagonista Eleni. Destaco também, embora tenham sido posteriores a O Convento, os filmes Carne trêmula (P. Almodovar, 1997), Cinzas do paraíso (Marcelo Pineyro, 1996) - sobre temas gregos neste, veja COELHO, 2006 -, e os dois épicos Helena de Tróia (J. Harrison, 2003) e Tróia (W. Petersen, 2004). 
convento perdido na Serra da Arrábida, situado em uma reserva na região de Setubal, em frente, curiosamente, à península que tem o nome 'Tróia'. Lugar bastante conhecido pelos portugueses (e certamente muitos europeus), trata-se de uma construção do século XVI, que desde 1250 já era um espaço religioso, após a chegada de Hildebrando, mercador das ilhas britânicas que ergueu uma ermida a Nossa Senhora, após se salvar de um naufrágio. ${ }^{21}$ Algumas destas informações são dadas no próprio filme, pois assim que chegam ao convento, o Professor Michael Padovic e sua esposa Hélène, fazem um passeio, guiados por Baltazar, um dos guardiões do convento. No entanto, antes deste passeio pelo interior do espaço reservado, vejamos a construção da primeira cena do filme. Logo após os letreiros com o nome do filme e do diretor, superpostos à imagem da chegada de um carro, dirigido por uma mulher, aos portões de uma propriedade em uma região serrana, em meio a árvores, aparece a frase: “Quem neste convento entrar, não ver, não ouvir e calar". Esta primeira advertência é interessante por duas razões. Inicialmente, considerando a relação complexa espectador-filme, nós ouviremos e veremos tudo que será falado, ouvido e visto no convento - a frase é quase um oxímoro, encaixando-se naquilo que Agustina Bessa-Luís comentou a respeito de Manoel de Oliveira: que "no auge duma verdade, deixa que o gosto da mentira o intercepte. "Ah! O gosto de mentir com a verdade na mão!". ${ }^{22}$ Em segundo lugar, ela remete a clássicos do cinema que lidam com esta relação paradoxal entre o segredo, a trama

${ }^{21}$ Lembremos que já na tradição grega helenística, Helena era a protetora dos marinheiros, que a ela apelavam para evitar naufrágios, o que não deixa de ser curioso.

${ }^{22}$ AVELLA, 2007, p. 48. 
escondida e a compreensão do espectador como vidente privilegiado. Apenas para citar dois exemplos, lembremos da cena inicial do clássico Cidadão Kane, com a câmera que entra no espaço proibido da propriedade, do poderoso magnata, apesar da advertência: "No trespassing", ou do filme The fugitive kind, baseado na peça Orpheus Descending, de T. Williams, em que Val (Marlon Brando), um Orfeu moderno, faz sua catábase ao atravessar uma fronteira (que o levará a um espaço infernal), marcada pela placa "Mississippi law. Stop". ${ }^{23}$ Assim, vemos que, se por várias características Manoel de Oliveira faz um cinema bastante singular, por outras, faz filmes que se encaixam na mais canônica tradição.

Voltando ao convento, todas as cenas iniciais, em que aparece o casal chegando ao local, são filmadas em planos gerais ou médios, e apenas as estátuas por entre as quais eles passam são mostradas em close. O primeiro close de pessoas é dado no rosto de Baltar, no momento em que, ao ser apresentado a Hélène por Michael Padovic, se abaixa e insere parte de seu corpo pela porta do carro. Por meio do close no rosto de Baltar nota-se sua expressão de vislumbre ao ver Hélène, de quem primeiro ouvimos apenas a voz, respondendo a Baltar, que se apresenta como o guardião do convento. Realcemos que apenas após ouvirmos a voz de Hélène e percebermos o olhar de Baltar é que o rosto da bela esposa do professor Padovic é mostrado, em close.

Baltar, analogamente a Mefistófeles, irá perturbar o Professor Padovic (aqui na situação análoga à de Fausto) tanto colocando a jovem Piedade no seu caminho, como sua assistente na biblioteca, como sugerindo que por meio da inovadora teoria sobre a ascendência espanhola de Shakespeare - hipótese que motivou as pesquisas de Padovic na biblioteca do

${ }^{23}$ Sobre esta releitura do mito de Orfeu, veja COELHO, 2008b. 
convento -, ele poderá alcançar a imortalidade. Em certo momento, Baltar leva Padovic ao cume de uma montanha nos arredores da construção sacra, para fazê-lo se sentir no topo do mundo e sugerir que sua descoberta o fará imortal; quando o professor comenta que Baltar fala como o demônio, o guardião diz apenas que é um humilde servo. Note-se, ainda, que logo no início do filme, fica claro para o espectador e para Baltar, que Hélène sente ciúmes do marido, por este dar mais importância à tese que quer provar do que a ela. Após conhecer Piedade, que além de bela e jovem, tem apreço pelo trabalho intelectual de Padovic, Hélène aparecerá ainda mais incomodada. Na nota de intenções do filme, como material de divulgação, Oliveira disse que a normalidade do casal se pautava pelo que ele concebia: "uma vida normal não deve ser mais do que aquela em que as duas forças opostas estão equilibradas, numa simbiose perfeita ou ideal." Este equilíbrio, ainda que medíocre, aparecerá no fim do filme, quando, as personagens de Piedade e Baltar, tiverem desaparecido, e, paradoxalmente, veremos que a figura angelical da jovem parece tão perturbadora como aquela diabólica de Baltar.

Piedade tem uma aparência serena, sempre vestida de cores claras, como o azul celeste, e com modéstia, em oposição ao estilo requintado de Hélène, sempre em cores negras e com os cabelos e maquiagem impecáveis e exuberantes. Nesse sentido, ela tem certa pureza e inocência de Margarida, do Fausto, embora Baltazar e Berta - outra funcionária do convento -, em certo momento, discutam a possibilidade de ser ela tão inocente. ${ }^{24}$ Baltazar e da Berta, que é astróloga, são uma dupla estranha: saem à noite pelo convento, olhando os outros a

${ }^{24}$ Neste filme, não seria especulativo, creio, ver, na releitura do Fausto, Margarida como uma outra face de Helena. 
dormir, invocando Satanás e praticando rituais um tanto macabros, além de ridicularizar a vida monástica dos antigos frades. Também é insinuado terem uma relação amorosa. Por outro lado, podem ser vistos no papel de comentadores da ação, algo análogo ao papel de um coro de tragédia grega. Embora o trabalho dos dois atores que os interpretam não seja muito convincente, suas informações são importantes para compreensão do filme. Em uma conversa entre Baltazar e Berta, a proximidade entre Piedade e Hélène, é explicitamente apresentada.

- [Baltazar ] Esta Hélène é uma mulher mistérios....

- [Berta ] E Piedade não é menos. Ambas estão fora de todos os padrões astrais...

- [Baltazar ] Mas tu não me tinhas dito que elas eram do signo de gêmeos.

- [Berta ] Sim, parecia-me que sim, mas elas fogem a dar mais detalhes, tudo nelas é muito enigmático [....] Hélène é muito perigosa....

- [Baltazar ] [...] E o Baltar, que que tu dizes de Baltar?.

- [Berta ] Ele devia desconfiar de Hélène. Está completamente manipulado....E por estranho que pareça o demônio do Baltar, aquele finório nem se dá conta.

Algo estranho em Piedade é também notado por Padovic, que em certo momento diz a sua assistente: "Você é uma estranha criatura que me lembra Penélope". A devoção dela ao professor é vista por ele na perspectiva da fidelidade de Penélope, "a fiel esposa de Ulisses que defendeu seus interesses", como ele diz, estabelecendo uma semelhança que, apresentada no momento no qual Piedade folheia uma edição alemã do Fausto, a surpreende. Neste momento, ela faz a leitura do texto de Goethe para Padovic, traduzindo diretamente do alemão, e enquanto lê justamente uma passagem sobre Mefistófeles, entra Baltar, em quem a câmera se detém. Estas alusões aos 
personagens de Goethe perpassam todo o filme. Posteriormente, alguns versos do Fausto serão recitados por Baltar e Hèlène (em francês) na praia, enquanto Padovic, que estava em companhia deles, afastou-se voltando à biblioteca, onde deixara Piedade. Concomitantemente, Baltar e Hélène saem de barco e vão a uma gruta (comparada por Hélène a uma vulva) e ali Baltar, de joelhos, declara seu amor a Hélène, que o repele com elegância. A partir deste momento teremos um conjunto de cenas alternadas entre Piedade e Padovic e de Baltar e Hélène, sugerindo as relações complexas e ambíguas entre bem e mal, bondade e maldade, desejo e sublimação. O professor diz que Piedade é de uma "pureza cruel', enquanto Baltar diz amar ouvir Helena falar como uma 'bruxa', quando estão no interior da caverna. Posteriormente, em uma cena durante a noite, a simbiose entre as personagens de Piedade e de Hélène é ainda mais inquietante: Padovic entra no quarto de Piedade e a toca, dando-lhe um beijo, depois aparecem apenas Hélène e Piedade suspirando e se mexendo de maneira análoga, como se reagindo a presença de outro corpo , como se sentissem a presença não apenas do professor, mas de outro ser que as tocasse. Isso fica mais claro quando, na manhã seguinte, Piedade revela ao professor um sonho com um anjo que desceu sobre seu corpo (e chama o professor de Michael, e não pelo sobrenome, como vinha fazendo até então; isso é significativo, pois Michael é uma das formas do nome de um anjo importante na tradição cristã ${ }^{25}$ ). Esta revelação coincide com o momento em que Padovic mostra a capa do livro Fausto que ele acabara de ganhar de presente de Piedade, facilmente reconhecida por ser a edição da editora

${ }^{25}$ Citemos, por exemplo, Apocalipse, 12:7: "Houve então uma batalha no céu: Miguel e seus Anjos guerrearam contra o Dragão. O Dragão batalhou, juntamente com seus Anjos, mas foi derrotado, e não se encontrou mais um lugar para eles no céu". 
Penguin, em inglês, pois o professor não lia em alemão, como Piedade lia. Esta capa tem um ser alado, mas no caso é uma figura assustadora. Talvez isso mostre, visualmente, uma faceta de Piedade que já havia sido indicada antes, quando, ao ver uma imagem em uma capela, ao lado do Professor Padovic, ela disse "Eu gosto muito da estátua de Maria Madalena"...." gosto do jeito que ela está deteriorada".

Nessa altura, a polaridade entre forças do bem e do mal torna-se mais complexa, pois Baltar, influenciado por Héléne, ainda que também atraído por Piedade, leva esta última para passear na floresta que circunda o convento, espaço sinistro e perigoso. No centro desta floresta havia um sorvedouro dos instintos em 'estado de pureza', como o próprio Baltar havia, antes, explicado a Hélène, em um momento que, seduzido pelo charme de sua amada, ele prometeu vingá-la, fazendo Piedade desaparecer - não porque Hélène amasse Padovic e tivesse ciúme do marido com a bela e cândida assistente, mas porque ela estava com o orgulho ferido e não queria ver Piedade entregar-se a Padovic. Neste segundo momento na floresta, no qual Baltar implementa o plano de fazer com que Piedade desapareça, ele tem uma longa conversa com a jovem, dizendo, dentre outras coisas, que não é humano. Por outro lado, candidamente, Piedade diz que está feliz por ter sido levada à floresta, onde ela se sente tão à vontade como se estivesse no jardim da infância. Ao ser interrogada por Baltar sobre seu sentimento por ele - pergunta capciosa da parte do guardião, em que insinua, também, que ela tem uma "fascinação" (erótica) pelo professor, o que Piedade descarta - ela revela que sente, sim, uma "fascinação", mas por Baltar. Mais precisamente ela explica: "Se alguém me fascinou desde o primeiro instante que o vi, foi o senhor Baltar [...] fascínio estranho como o de pai sobre uma filha...fascinação respeitosa, como uma filha sente por um 
pai". ${ }^{26}$ Vemos claramente como ele fica encabulado com a falta de desejo mais humano em Piedade, seu desinteresse pelas empresas humanas e orgulho em realizá-las. Após uma longa conversa, Piedade lhe confessa algo inesperado - algo que ela sente profundamente - e que o excita. Quando ela diz a ele que tem saudades de Deus, tal revelação o deixa completamente atordoado. ${ }^{27}$ Nesse momento, Piedade se afasta e caminha para algo que ela vê e a deslumbra, no centro da mata, mas que nós não vemos. Quando volta a si, Baltar já a vê de longe, correndo pelos galhos retorcidos. Ele, desesperado, grita para que ela volte, sem sucesso, porém. É a última vez que a vemos, no seu vestido azul e com sua longa trança, desaparecendo no verde intenso. Ao mesmo tempo em que ele a vê sumir dentro da floresta, Padovic também sussurra o nome de Piedade e vai à sua procura por todo convento. Não a encontrando, retorna à biblioteca e lê em voz alta um trecho do Fausto de Goethe, em uma página que já estava aberta, deixada ali por Hélène, em um momento em que ela havia visitado seu marido na biblioteca e folheado o livro de Goethe. Padovic, enquanto lê um trecho, faz também comentários, como se estivesse interpretando o significado da fala de Helena no Fausto. Transcrevo, abaixo, parte do texto desta cena:

${ }^{26}$ No romance de Agustina Bessa-Luís, Baltar é casado e tem uma relação estranha com suas filhas. De modo minimalista, o filme parece aludir a isto ao fazer Piedade considerá-lo como um pai a que ela se submete.

${ }^{27} \mathrm{O}$ tema da saudade (e da memória e do paraíso perdido) parece ser também uma questão muito importante para Manoel de Oliveira, conforme podemos inferir a partir das conversas registradas entre ele e Agustina Bessa-Luís, nas quais ele diz "Saudade não é do que se passou, e sim saudade do que há-de vir [...] é o "Quinto império". No fundo é a União Européia", a união dos povos. É a harmonia, é tudo aquilo que é irrealizável na Terra.", AVELLA, 2007, p. 61-63 e 72-74. 
'Cheguei com o meu senhor num navio. Sei que devo procurar a sua cidade. Mas que intenção será a sua que não posso adivinhar? Terei vindo como esposa? Virei como rainha? Ou serei uma vítima das angústias de meu príncipe e dos trágicos destinos desde há muito sofridos pelos gregos?' Sim, a Helena de Tróia tinha o dom da ubiqüidade. Por que não? Já vi isso escrito em algum lugar, é o poder de se transformar.

Padovic deixa a biblioteca e vai de carro à praia, onde se senta nas pedras. De repente, no mar brilhante e calmo, vê Hélène saindo das águas, qual Afrodite anadyomene; ela, de quem só vemos o rosto e depois os pés, pega uma túnica branca disposta cuidadosamente sobre a areia, com barrados com fitas gregas desenhadas, a veste e sai abraçada com o marido, tendo, antes, lhe dado um abraço, em uma cena padrão que é mostrada apenas pelo movimento dos pés do casal, na qual um dos pés da mulher se levanta do chão, delicadamente. Tudo se passa na presença do pescador, que já fora mostrado em cenas anteriores, e que os olha com expressão algo espantada, algo curiosa. $\mathrm{O}$ filme termina com a seguinte informação na tela:

Um pescador contou que naquele mesmo dia houve um grande incêndio no bosque, pondo em perigo aquele raro exemplar da era jurássica. E que Hélène e Michael partiram sem demora com roupas e livros. Que Piedade e Baltar, dados por desaparecidos depois do incêndio, foram substituídos por Berta e Baltazar no Convento. O pescador ouviu ainda dizer que Hélène e Michael faziam agora uma vida vulgar em Paris, e que o Professor abandonara as antigas pesquisas para se debruçar a fundo sobre as ciências ocultas. Mas não devemos acreditar em tudo o que o pescador diz.

Não devemos mesmo? A túnica vestida por Hélène confirma, imageticamente, a suposição de Padovic da ubiquidade 
de Helena, sobre quem ele acabara de ler nos versos do livro que a própria Hélène havia deixado no seu escritório, já aberto naquela página. Não podemos descartar, ainda, que Piedade seja uma epifania de Helena. Aqui reverberam o verso de Goethe, que citamos antes, e a casta Helena da tragédia homônima de Eurípides. No filme, Helena de Tróia se manifesta, a meu ver, nestas duas mulheres, tão distantes e tão próximas, como mostra, também, uma cena muito significativa, em que, ao entrar na biblioteca para visitar o marido, Hélène é vista por Michael como Piedade: em uma fusão das imagens das duas mulheres, Piedade está caracterizada com o corte de cabelo e as roupas de Hélène. Vemos, então, como, visualmente, Manuel de Oliveira reforçou esta ambiguidade, com a qual o mito grego já trabalhava. Para concluir este artigo, gostaria de fazer algumas considerações sobre o texto de Agustina BessaLuís, escrito paralelamente à elaboração do filme. Realço a singularidade da relação entre literatura e cinema neste caso, em que o olhar do grande diretor de cinema não partiu do texto da grande escritora, mas ambos partiram de uma idéia comum - um argumento criado por Agustina a pedido de Manoel e contado a ele, e desta matriz os dois fizeram suas obras. A princípio, o livro se chamaria Pedra de toque, mas este título foi mudado para As terras do risco e o filme ficou com o nome $O$ convento. Se os problemas de tradução de uma língua a outra já são muitos e complexos, aqueles de uma linguagem a outra, principalmente uma considerada de "alta cultura" para outra de "cultura de massa", são ainda mais delicados (penso no cinema como linguagem, embora esta convicção demande maior justificativa $\left.{ }^{28}\right)$. Soma-se a esta dificuldade mais geral

${ }^{28}$ Lembremos que o debate não é recente (veja, por exemplo, de EISENSTEIN, 1990, p. 13 a 47. Em relação ao tema sobre língua e linguagem no cinema, veja STAM, 2003, cap. 15, 16 e 28. 
aquela de lidar com o tratamento de questões específicas, como o conceito de 'adaptação' - como realcei nem é este exatamente o caso singular ocorrido aqui. Não pretendo, neste artigo, debruçar-me sobre temas teóricos relativos ao estatuto da imagem frente ao texto escrito e às querelas sobre a 'fidelidade' ao texto, ou à tradição iconoclasta ocidental (influenciada por pressupostos religiosos e filosóficos ${ }^{29}$ ), tampouco sobre o significado de conceitos/práticas de adaptação, sua tipologia e seus correlatos (transposição, transcriação, atualização,

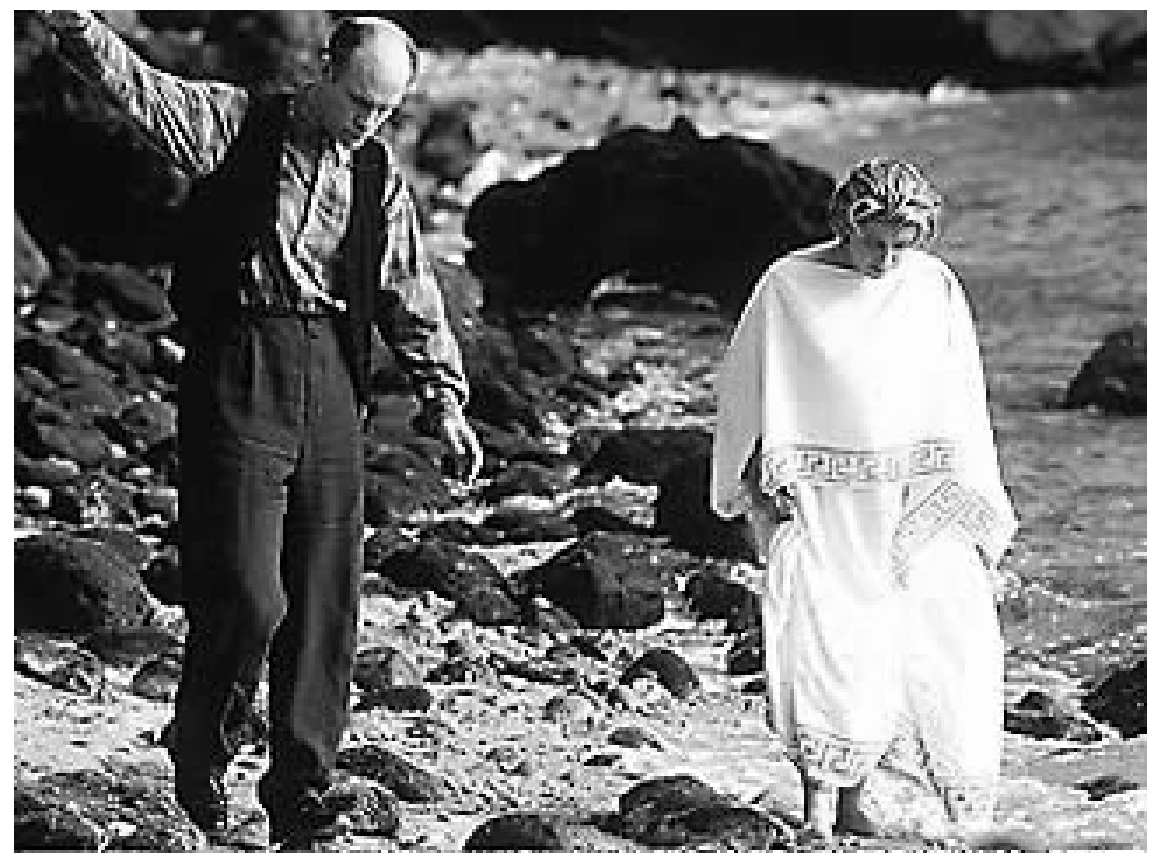

Still do filme $O$ convento (a cena não aparece no filme).

Disponível em: www.amordeperdicao.pt < base de dados> Acesso em: 20/09/2009.

${ }^{29}$ Sobre o tema, veja, por exemplo, AUMONT, 1995; BESANÇOM, 1997, e MACHADO, 2001, livros em que se tenta romper com a desconfiança em relação à dimensão ilusória e perigosa das imagens. 
dialogização, canibalização, transmutação, transfiguração, transcodificação, etc). Limitar-me-ei a algumas considerações e paralelismos entre as obras.

No livro de Agustina Bessa-Luís, As terras do risco, os personagens que vivem esta história, no período de quase dois anos no convento (p. 207) têm outros nomes, e a escolha operada por Oliveira já é significativa. ${ }^{30}$ Fabre Martin é o professor (que na verdade se chamava Arnould, mas trocara seu nome, p.9). $O$ nome de sua "bela esposa de enigmáticos olhos aparentemente sem segredos" era Jeanne Précieuse e antes de se casarem, Fabre a imaginava uma "Helena de Tróia em bicicleta" quando a conheceu em Montpellier. Ambos são franceses. Baltar e Piedade estão presentes no livro, mas o primeiro tem família. É um pai rigoroso e tem uma relação bastante possessiva com as filhas. Acaba sendo abandonado pela esposa e perdendo o poder sobre suas filhas, Piedade é formada em filosofia, e estudou um pouco de alta-costura (p. 18). No romance, as referências propositadamente ambíguas à Tróia grega e à portuguesa formam um jogo de espelhos em que o histórico e o mítico se misturam. Destaca-se, ainda, a utilização de várias passagens de peças de Shakespeare (principalmente Othello, Hamlet e Macbeth) para espelhar as situações de ciúme, desejo e inveja entre os personagens do livro. No entanto, são as referências ao Fausto e à Helena de Tróia as que aparecem ao longo de todo o livro com mais frequência, reforçadas por alusões a Penélope, Fedra, Ulisses, Dafne e Homero, indicando o peso da tradição grega na rede de significados do romance.

Em relação a Martin e Précieuse, várias passagens mostram, claramente, o diálogo da escritora com os textos de Goethe e com a literatura grega clássica. Destaco, inicialmente, duas comparações muito reveladoras. No caso de Martin é dito

${ }^{30}$ BESSA-LUIS, 1994. 
que ele "Sentia-se uma espécie de doutor Fausto, obcecado pelo propósito de descobrir o meio de alcançar a eternidade" (p. 133), no caso da mulher do professor, ela é descrita assim por Piedade (que a observa na praia, "em meio a tanta gente feia": "Précieuse é feita segundo o padrão grego. Olhos separados, testa não muito alta, os cabelos lisos e loiros dos aqueus. Tenho inveja dela" (p. 135). O narrador faz também um comentário muito significativo sobre Précieuse: "Não se parecia com nenhuma mulher da literatura, nem com Julieta, nem com a Cat barulhenta, nem com Marilyn, a carnuda e ociosa, mais inteligente do que era próprio para a educação que recebeu. Mas com Helena talvez tivesse afinidade" (p. 148). A semelhança entre Helena e Précieuse (e entre Martin e Fausto) é ainda muito clara aqui:

Helena foi quem melhor personificou o feminino no seu estado mais harmonioso [...] todos os homens, todos os povos a queriam como coroa de suas ações. [...] Em vias de buscar o segredo da eternidade, Fausto chamou-a através dos séculos já decorridos. E naquele vetusto convento da Arrábida, rompendo as cadeias do esquecimento que os portugueses tanto prezam, ela tomava outra vez uma forma palpável na figura de Précieuse. ${ }^{31}$

Como observamos antes, se as referências ao texto de Goethe são claras e constantes, também a presença da versão do mito do eídolon (cuja manifestação literária mais conhecida é a tragédia Helena, de Eurípides) é evidente:

Helena, que Martin fazia surgir dum oceano de fantasmagoria, tão bem materializado no mar da Arrábida, não pecara com Páris. Como dizia uma lenda que funcionara como um advogado de defesa, ela sofrera uma metamorfose, e outra,

${ }^{31}$ BESSA-LUIS, 1994, p. 207. 
e não ela, fora para Tróia, como outra esposa sem culpa. Só a sua beleza, e a natureza da beleza que era dotada de efeitos enganadores, se desprendera dos laços conjugais. $\mathrm{E}$ ela, a verdadeira Helena, ficara no lar, sem que fosse visível, porque a beleza e seu poder erotizante se despegara da alma dela. Tal a astúcia dos deuses! ${ }^{32}$

A própria discussão sobre a autoria feminina da Odisséia e a possibilidade de Shakespeare ter sido, na verdade, uma mulher - defendidas por Précieuse (p.120) realçam não apenas o debate sobre o poder que as mulheres deveriam ter e sobre a concepção da beleza como vontade de mando, como servem de elementos para uma reflexão sobre uma releitura pelas mãos de uma mulher, neste caso, Agustina Bessa-Luís. Quanto às alterações do enredo, mais do que reclamar de uma infidelidade a alguma versão consagrada como fonte, o interessante é analisar o porquê de certas alterações, que, aliás, nos dizem, às vezes, mais sobre a sociedade e a cultura nas quais estão inseridas do que sobre aquelas que se pretende retratar no caso deste filme, há inúmeras possibilidades de leituras, quando se atenta para a utilização ou evocação de outros textos literários ou iconográficos e cinematográficos, além do texto de Agustina Bessa-Luís, referência mais imediata. Quando Baltar cita, dentre os livros na biblioteca do convento, um fragmento de um romance inédito de Garrett, chamado Helena, Martin diz "Helena é um nome que vale por uma carta pastoral" (p. 17). Neste sentido, a obra de Agustina Bessa-Luís parece aludir ao trabalho do escritor de lidar com outras ficções e refletir sobre elas em sua própria obra. O final do filme de Manoel de Oliveira mostra, ainda, a possibilidade do diálogo entre obras ficcionais (tão próximas!) ao colocar na tela a imagem do mar e da praia, após Hélène (saindo nua do mar qual Afrodite, protetora de

32 BESSA-LUIS, 1994, p. 144. 
Helena) desaparecer em sua túnica branca de rainha, acompanhada pelo marido. Podemos colocá-lo, a meu ver, paralelamente a um diálogo no início do livro de Agustina Bessa-Luís entre Fabre e Précieuse, quando estão a caminho do convento, e no qual estes elementos marítimos e o poder de Helena já estão indicados:

- Vou dizer-te: "O capitão Fabius teve um destino trágico, casou-se".

- Estás a inventar.

- Não estou. O que acontece é que ninguém leu Notre-dame até o fim. Senão havia de ficar muito surpreendido com aquele Victor Hugo, cínico e alegre como um pintassilgo. Acabar um romance dá com certeza idéias destas.

- É possível - disse madame. Era uma mulher linda e absolutamente convencida de que Molière tinha dito tudo ao definir a base do autor teatral: "a grande regra é agradar". Posto que as mulheres bonitas, quer queiram quer não, vivem num palco, essa regra serve-lhes às mil maravilhas. Madame tirou o chapéu como quem depõe uma coroa e disse:

- O mar é um mistério. ${ }^{33}$

Com esta citação termino este artigo, que buscou fornecer não apenas alguns elementos para a compreensão da construção de personagens femininas inspiradas na tão famosa ebela Helena (na literatura e no cinema), mas também indicar a singularidade deste filme de Oliveira (e também da obra de Bessa-Luis, embora tenhamos nos detido principalmente no primeiro), ao fazer a bela espartana - mas sempre dita troiana -, viver com todo seu fausto em um convento, de onde irá partir para uma prosaica vida privada em Paris. Le coeur a ses raisons, que la raison ne connaît point..., aposta Manoel de Oliveira na (ir)racionalidade

${ }^{33}$ BESSA-LUIS, 1994, p. 9. 
da preciosa personagem agustiniana, transformando em imagens o mistério do mar seja na figura do pescador, seja na imagem muda e de olhos vendados do monge franciscano com uma chave no coração. E só nos resta acreditar na fábula do pescador/diretor.

\section{Bibliografia}

AUMONT, Jaques. A imagem. Campinas: Papirus, 1995.

AUSTIN, Norman. Helen of Troy and her Shameless Phantom. Ithaca: Cornell, 1994.

AVELLA, Aniello A. (Org.). Um concerto em tom de conversa. Belo Horizonte: Ed. UFMG, 2007.

BASSI, Karen. Helen and the discourse of denial in Stesichorus' Palinode. Arethusa 26, p. 51-75, 1993.

BESANÇON, Alain. A imagem proibida. História intelectual da iconoclastia. Rio de Janeiro: Editora Bertrand Brasil, 1997.

BESSA-LUIS, Agustina. As terras do risco. Lisboa: Guimarães Editora, 1994.

BOWRA, Cecil. Greek Lyric Poetry. Oxford: Clarendon Press, 1961.

CALAME, Claude. Hélène. In: Dictionnaire des mythologies. Y. Bonnefoy (Ed.). Paris: Flamarion, 1981.

CASSIN, Barbara.Voir Hélène en toute femme. Paris: Flamarion, 2001.

COELHO, Maria Cecília M. N. Górgias: Elogio de Helena e Tratado do não-ser. Tradução do grego com introdução e notas. Cadernos de Tradução, n. 4, São Paulo, Departamento de Filosofia/USP, 1999.

COELHO, Maria Cecília M. N. Imagens de Helena. Clássica, 13/14, p. 159-172, 2000.

COELHO, Maria Cecília M. N. Helena, Euripides e Machado de Assis. Espelho, Purdue, v. 8/9, p. 37-62, 2002a. 
COELHO, Maria Cecília M. N. Eurípides, Helena e a demarcação entre retórica e filosofia. Tese (Doutorado em Letras Clássicas), Universidade de São Paulo, 2002b.

COELHO, Maria Cecília M. N. Helena: de Tróia ao cinema latinoamericano: Cinzas do paraíso, de Marcelo Pineyro. Argos, v. 30, p. 6583, 2006.

COELHO, Maria Cecília M. N. Helena de Tróia no cinema: metamorfoses do mito. $2^{\circ}$ SIMPÓSIO DE ESTUDOS CLÁSSICOS DA USP. Anais... São Paulo: Humanitas, 2007. p. 131-159.

COELHO, Maria Cecília M. N. Diderot em preto e branco: as paixões de $\mathrm{M}^{\text {lle }} \mathrm{d}^{\prime}$ Aisnon e de $\mathrm{M}^{\text {me }}$ de La Pommeraye segundo Robert Bresson. Rapsódia, p. 65-96, 2008a.

COELHO, Maria Cecília M. N. Entre a história e o mito - Orfeu na América, segundo Sidney Lumet. Artcultura, v. 10, n. 17, p. 221-235, 2008b. Disponível em: http://www.artcultura.inhis.ufu.br/ PDF17/M_Coelho_17.pdf. Acesso em: 12/5/2010.

COELHO, Maria Cecília M. N. As afecções do corpo e da alma e a analogia entre pharmakon e logos, a partir de Górgias. In: PEIXOTO, Miriam (Org.). Saúde do homem - reflexões gregas e romanas. São Paulo: Loyola , 2009. p. 67-86.

COELHO, Maria Cecília M. N. Entre o mito e a história: as adaptações de Duas vezes com Helena, de Paulo Emílio Sales Gomes. Nuevo Mundo Mundos Nuevos, Cuestiones del tiempo presente, 2010. Disponível em: http:/ / nuevomundo.revues.org/58334. Acesso em: 4/5/2010.

EISENSTEIN, Seguei. Palavra e imagem. In: XAVIER, Ismail (Org.). A experiência do Cinema. São Paulo: Zahar, 1990. p. 13-47.

EISNER, Robert. Echoes of the Odyssey in Euripides' Helen. Maia 32, p. 31-37, 1980.

FOLEY, Helen. Anodos Dramas: Euripides' Alcestis and Helen. In: Ralph Hexter \& Daniel Selden. Innovations in Antiquity, Routledge, 1992. p. 133-160. 
GOETHE, Wolfgang. Fausto Zero Escritos 1773-1775. Trad. Christine Röhig. São Paulo: Ed. Cosac Naify, 2001.

GOETHE, Wolfgang. Fausto. Trad. Jane Klabin Segal. 3. ed. São Paulo: Villa Rica, 1991.

GUMPERT, Martin. Grafting Helen: The Abduction of the classical past. Madison: The University of Wisconsin Press, 2001.

KAKRIDIS, Johanes. Problems of the Homeric Helen. In: . Homer Revisited, Lund, 1972. p. 25-54.

MACHADO, Arlindo. O quarto iconoclasmo e outros ensaios hereges. Rio de Janeiro: Rios Ambiciosos, 2001.

MACHADO DE ASSIS. Obra Completa, vol. III. Ed. Nova Aguillar, 1997.

NIETZSCHE, Friedrich. O Nascimento da Tragédia. Trad. Jacó Guinsburg. São Paulo: Companhia das Letras, 1993.

OLIVEIRA, Manoel de. O convento. Produção: Mandrágora Filmes, 1995. DVD.

PAES, José Paulo. Poemas - Giorgos Seféris. Seleção, tradução, introdução e notas. São Paulo: Editora Nova Alexandria, 1995.

SEGAL, Charles. The Two Worlds of Euripides' Helen. In:

Interpreting Greek Tragedy: Myth, Poetry, Text. Ithaca: Cornell, 1986 (1971).

STAM, Robert. Introdução à Teoria do Cinema. São Paulo: Papirus, 2003, cap. 15, 16 e 28.

SUZUKI, Mihoko. Metamorphoses of Helen: Authority, Difference, and the Epic. Ithaca: Cornell, 1989. 


\section{Resumo}

O objetivo do artigo é analisar alguns aspectos da caracterização da personagem Hélène, no filme $O$ Convento (1995), de Manoel de Oliveira, comparando-a a personagem Précieuse, no livro As terras do risco (1994), de Agustina Bessa-Luís. Embora o filme tenha sido lançado em 1995, ele não é uma adaptação do livro. Este é um caso interessante na relação entre literatura e cinema. $\mathrm{O}$ argumento do romance originou o filme, mas são obras independentes. Em ambos, porém, busco mostrar como as protagonistas foram construídas a partir de referências às personagens de Helena de Tróia tanto de obras da literatura grega clássica como do Fausto, de Goethe.

\section{Abstract}

The aim of this article is to analyse some aspects of the characterization of the figure of Hélène in the film The Convent (1995), by Manoel de Oliveira, comparing her to the character Précieuse from the novel As terras do risco (Dangerous Lands, 1994) by Agustina Bessa-Luís. While the film was released in 1995, it is not an adaptation of the book, and this is an interesting case in the relationship between literature and cinema. The story of the novel formed the basis for the film, but they are independent works. In both, however, I seek to show how the protagonists were constructed from references to the character Helen of Troy, drawing as much from works of classical Greek literature as from Goethe's Faust. 